\title{
The Effect of Listening Mode on the Choice of Cognitive Strategies in Listening Comprehension
}

\author{
Rezvan Zonoubi \\ Islamic Azad university (Khorasgan branch), Esfahan, Iran \\ Email: rzonoobi@yahoo.com
}

\begin{abstract}
This paper aimed to investigate the effect of listening mode on the choice of cognitive strategies in listening comprehension. Eighty six intermediate students from Islamic Azad university (Najafabad branch) were administrated the audio-visual and only-audio versions of a test. Scores on the two test modes indicated no significant differences between the two groups. Moreover, this paper tried to see the use of cognitive strategies and tactics between the audio- visual and only-audio groups. The mean frequency of "the strategy inferencing" in only-audio group was 14 which was higher than the audio- visual group while the mean frequency of other strategies was higher in audio-visual group. The results of Chi- square tests for tactics indicate that there is a statistical difference between the two groups in terms of "other surrounding key words" and 'information from pictures or the speakers' tactics.
\end{abstract}

Index Terms - audio-visual, only-audio, cognitive strategies, tactics

\section{INTRODUCTION}

Understanding and comprehending spoken language is fundamentally an inferential process (Rost, 2002). Listeners apply both linguistic knowledge and world knowledge to create a mental representation of what they have heard (Hulstijn, 2003). For applying these knowledge sources listeners use top-down and bottom-up processes (Lynch \& Mendelsohn, 2002; Rost, 2002; Flowerdew \& Miller 2005). Listeners favor bottom up process when they construct the meaning from the smallest unit of spoken language to the largest one in a linear mode (Nunan 1998). Thus, learners try to decode a number of sounds to form words, words are joined to form phrases and phrases are joined to make up sentences. These sentences make a complete text, whose meaning is constructed by listeners. Besides grammatical relations, other features such as stress, rhythm and intonation contribute to this data- driving processing (Van Duzer, 1997). Listeners favor top- down processes when they interpret meaning as intented by speakers by means of schemata or structures of knowledge in the mind (Nunan, 1998). Top-down processing highlights the importance of prior knowledge used by learners in comprehension of what they hear. While there is belief that these processes interact in some form of parallel distributed processing (Bechtel \& Abrahamsen 1991), the degree of using one process more than the other will depend on purpose for listening, learner characteristics such as level of language proficiency, and the context of the listening event. A listener who is looking for details engage in more bottom-up processing than a listener who is interested in comprehending the main point of a text. The degree of L2 learners' ability in processing spoken language can influence the speed and effectiveness of these processes. (Segalowitz, 2003).

Nowadays videos play an important and common role in teaching listening and its use of video has been recommended in English language teaching for a number of reasons. (McGovern, 1983; Lonergan, 1984; Allan, 1985). As a pedagogical tool, video offers a considerable enhancement over simple audio alone. Some of these benefits relate to context and discourse (Geddes and White, 1978), paralinguistic features (Stempleski and Arcario, 1992), as well as aspects of culture (Phillips, 1995). Altman (1990) suggests that video enhances the listening process because it enables listeners to get clues from what speakers say or may be going to say often before the utterance is heard. Secules et al. (1992) suggest that video gives second language learners this chance to observe the dynamics of interaction as they see native speakers in authentic settings speaking and using different accents, registers, and paralinguistic cues (such as posture, gestures).

In spite of the importance of nonverbal communication in L2 production (e.g., McCafferty, 2002), little research has been done on the effects of visual cues on EFL learners' listening comprehension. Whether visual information generally increases comprehension is still open to doubt. Moreover, Successful listening can be looked at in terms of the strategies the listener makes use of when listening. Does the learner focus mainly on the content of a text, or does he or she also consider how to listen? A focus on how to listen raises the issues of listening strategies. Accordingly, the main objective of this study was to answer the following questions:

1. Are EFL learners better at comprehending audio-visual materials than an only-audio material?

2. Do EFL learners use the same cognitive strategies and sub-strategies for audio-visual listening and only audio listening comprehension?

\section{REVIEW OF LITERATURE}


Definitions for "learning strategies" are filled with much disagreement of exactly what learning strategies are or if they really exist. In the Concise Encyclopedia of Educational Linguistics (1999), Oxford suggests this definition: Learning strategies for second or foreign language learners are "specific actions, behaviors, steps, or techniques that students use to improve their own progress in developing skills in a second or foreign language. These strategies can facilitate the internalization, storage, retrieval, or use of the new language" (p. 518).

There is no definite list of learning strategies although hundreds of strategies used by language learners may exist (Oxford, 1996); Different types of learning strategies have been offered in response to different research projects. Macaro (2006) mentioned that the main difficulty in the study of learning strategies centers on a lack of clarity in both definition and classification of learning strategies. Vandergrift, (2003) suggested three types of strategies, metacognitive, cognitive, and socio-affective. Another very popular and frequently used strategy inventory was developed by Oxford (1990) who proposed six different categories of learning strategies. Oxford used factor analysis to group strategies into the following: Cognitive, metacognitive, memory-related, compensatory, affective, and social strategies. Macaro (2001) classified strategies on a multi-level continuum with, cognitive strategies at one end and metacognitive/social/affective at the other. In his more recent work, Macaro (2006) preferred to classify learning strategies as either cognitive or metacognitive, claiming that metacognitive subsumes the socio-affective domains. In an attempt to bring many of the categorizations of strategies together, Dörnyei (2006) proposed a typology with four types of strategies:

1) Cognitive strategies, involving the manipulation or transformation of the learning materials/input (e.g., repetition, summarizing, using images).

2) Metacognitive strategies, involving higher-order strategies aimed at analyzing, monitoring, evaluating, planning, and organizing ones' own learning process.

3) Social strategies, involving interpersonal behaviors aimed at increasing the amount of L2 communication and practice the learner undertakes (e.g., initiating interaction with native speakers, cooperating with peers).

4) Affective strategies, involving taking control of the emotional (affective) conditions and experiences that shape one's subjective involvement in learning. (p. 169).

Some research makes the distinction between general and specific strategies. This distinction, however, does not sufficiently differentiate a general strategy from its operationalisation. The term "tactic" is used to refer to individual techniques through which general strategy is operationalised (following Snowman, 1986; Schmeck, 1988). For example, we may say that a strategy such as "inferencing" can be operationalised through tactics such as "other surrounding key words, experience and knowledge about the topic, knowledge about the English language, information from pictures or speaker's expression and knowledge about the situation.

Asking learners what strategies they are using or have just used and observing learners to determine what they are doing at any given time are the methods for assessing strategy use which provide useful feedback. (Macaro, 2001). These methods are the prevalent ones used in recent research studies and the best way invented to date (Chamot, 2005).

Research on the mode of input for listening assessment is getting more attention with the increased availability of multimedia and digital technology. Test developers are interested in discovering the relevance and usefulness of visual support in the assessment of L2 listening. Coniam (2001)) did a case study in which a group of pre-service and inservice English language teachers were administered audio and video versions of the same test. Scores on the two test modes showed no significant differences between the two groups. Further, although some of the test takers from the audio test-taking group said they would have preferred to have taken the test via video, the video test-taking group felt that not only had they gained no advantage from the video mode, they felt they might have done better had they not been distracted by the visual images, and by having to look up and down from question paper to screen. In contrast to the listeners in the Coniam's study, the listeners in Wagner's study (2007) supported the use of videotext in listening assessment and did not find video distracting. Similar findings were reported by Feak \& Salehzadeh (2001) concerning the development and validation of a listening placement test using video. Ginther (2002) investigated the relative effect of two kinds of visuals on the comprehension of mini-talks in the computerized TOEFL test. Content visuals (pictures related to the actual content of the verbal exchange) slightly enhanced comprehension; however, context visuals (pictures that set the scene for the upcoming verbal exchange) were found to be less useful. Tina Lynn Ware (1999) did a research titled "a comparison of audio- only versus audio - visual second language instruction in first year universitylevel Spanish". In her study, she tried to investigate whether the traditionally used audio-only or the more modern audio- visual language learning laboratory activities would be more effective in helping students build skills in listening comprehension, reading comprehension and listening/reading comprehension in Spanish. The results of the study demonstrated that there was no significant difference between the two groups in listening comprehension. Lund, 1990; Chung, 1994; Secudes, Herron, Tomasello\& Meunier-Cinko 1992 found that students who used the French in Action video tapes had higher test scores in the area of listening comprehension and with the questions that involved main ideas, details, and inferences than had those who did not use the videos.

\section{Methodology}

\section{A. Participants}

Initially 120 sophomore students from Najafabad Islamic Azada University majoring in TEFL were selected for this study. All the participants took part in an Oxford Placement Test. Those students who scored one standard deviation 
below and one standard deviation above the mean were selected for the main study. Only 86 students at the intermediate level of language proficiency were selected. Of these 86 students who were at different age levels, 50 students were female and 16 were male.

\section{B. Materials}

Oxford Placement Test: This test has two subtests. The first subtest is a listening test with 100 items. Each item has two choices and students were asked to tick the word they hear. The second subtest is a grammar test including 100 items each having three choices for each item. The test naturally starts with some examples which help students to do the test.

"How Do You Do" video and cassette: Initially several educational movies which were available in the market were selected. After talking to the instructors of the course, the decision was made to choose "How Do You Do" because some instructors had already provided their students with the other two movies in their classes so students were familiar with two of them and they could not be used. Moreover, some of movies were too short or too long and some of them were difficult in administrating. Finally, according to the instructors' suggestions, ease of administration and appropriateness, "How Do You Do" was chosen. In this movie, Dr Frankie Stone and her robot invention, CHIPS, can help newcomers learn English or improve their ability in learning English. "How Do You Do" movie has 24 sections and each section focuses on a theme (such as, food, clothing, employment) and consists of segments that provide documentary information, vocabulary, interviews with English speakers from many cultures and ideas for applying the material learned. In this study, section 'Workplace' (22) was randomly chosen in which CHIPS learns about working conditions, employee benefits, and how to read a pay check.

Questionnaire: To collect information concerning the type of cognitive strategies used by EFL learners, the participants were asked to fill out a questionnaire. This questionnaire was a modified version of Goh's (2002) TELL (Techniques for Learning to Listen) questionnaire.

\section{Procedures}

All the materials including OPT test, "How Do You Do" comprehension questions, and questionnaire were piloted before the main study. The pilot study subjects were all sophomore students majoring in TEFL in Islamic Azad University ( Najafabad branch). The aim of piloting OPT was to know about the instructions of the test, that is, whether they are clear or need a pre- explanation before test implementation. The purpose for piloting "How Do You Do" comprehension questions was to check both the stem and the choices. Before watching the movie or listening to the cassette, the subjects were allowed to look at the questions and ask wherever they could not understand. Then, they were asked to answer the questions while they were watching or listening to "How Do You Do". After collecting the data, item facility and item difficulty of each question was calculated and too easy and too difficult items were removed and new items were replaced. Moreover, the adopted Goh's questionnaire was administered and piloted. It was translated in to the participants' native language and subjects were allowed to ask any question during the filling of the questionnaire.

For the main study, 120 sophomore students majoring in TEFL in Najafabad Islamic Azad University were administered OPT. This test includes two parts. The first part consists of 100 listening questions which have two choices. Students were asked to listen and tick the word they hear. The tape was neither stopped nor repeated. It took 10 minutes to finish this section. The second section is the grammar section which includes 100 items with three choices. Students completed this part of test in fifty minuets and they simply answered by ticking the boxes. By referring to OPT scores, 86 intermediate students were selected for "How Do You Do" test. Students were randomly divided in to two groups of 43 each. The first group was provided with an only audio Cassette of "How Do You Do" and the second group was provided with an audio- visual tape of the movie. Then both groups were asked to answer 20 multiple-choice comprehension questions while they were listening or watching "How Do You Do". After finishing this part, they were given the questionnaire to choose among those 18 cognitive strategies and tactics when they were listening or watching. These two parts took about 45 minutes.

\section{RESULTS}

The first research hypothesis was: "There is no difference between the students' comprehension of the audio-visual materials and only- audio materials."

In order to investigate the after-mentioned hypothesis, an independent-samples t-test was conducted to compare "How Do You Do" listening scores for audio- visual and only audio group. The descriptive statistics of the scores are shown in table 1:

TABLE 1:

DESCRIPTIVE STATISTICS FOR AUDIO-VISUAL AND ONLY AUDIO GROUPS

\begin{tabular}{|l|l|l|l|l|}
\hline group & $\mathrm{N}$ & Mean & Std. Deviation & Std. Error Mean \\
\hline Audio-visual & 43 & 12.6279 & 3.57254 & 0.54481 \\
\hline Only -audio & 43 & 11.2558 & 4.00650 & 0.61099 \\
\hline
\end{tabular}


TABLE 2:

INDEPENDENT SAMPLES T-TEST FOR AUDIO-VISUAL AND ONLY AUDIO GROUPS

Independent Samples Test

\begin{tabular}{|c|c|c|c|c|c|c|}
\hline & \multicolumn{2}{|c|}{$\begin{array}{l}\text { Levene's Test for } \\
\text { Equality of Variances }\end{array}$} & \multicolumn{3}{|c|}{ t-test for Equality of Means } \\
\hline & & $\mathrm{F}$ & Sig. & $\mathrm{t}$ & df & Sig. (2-tailed) \\
\hline score & $\begin{array}{l}\text { Equal variances assumec } \\
\text { Equal variances not } \\
\text { assumed }\end{array}$ & .439 & .510 & $\begin{array}{l}1.676 \\
1.676\end{array}$ & $\begin{array}{r}84 \\
82.920\end{array}$ & $\begin{array}{l}.097 \\
.097\end{array}$ \\
\hline
\end{tabular}

The result indicates that there was no statistically significant difference between the performances of the audio-visual $(\underline{\mathrm{M}}=12.62, \underline{\mathrm{SD}}=3.57)$ or only audio $(\underline{\mathrm{M}}=11.25, \underline{\mathrm{SD}}=4)$ groups regarding "How Do You Do" listening comprehension scores.

The second research hypothesis was: "There is no difference between the cognitive strategies and tactics that EFL learners use for audio-visual and onl audio materials in listening comprehension".

In order to test the second hypothesis, the mean frequency scores of five strategies (inferencing, prediction, translation, visualization, fixation, and contextualization) which were used by both groups were calculated. The results are shown in the following figures:

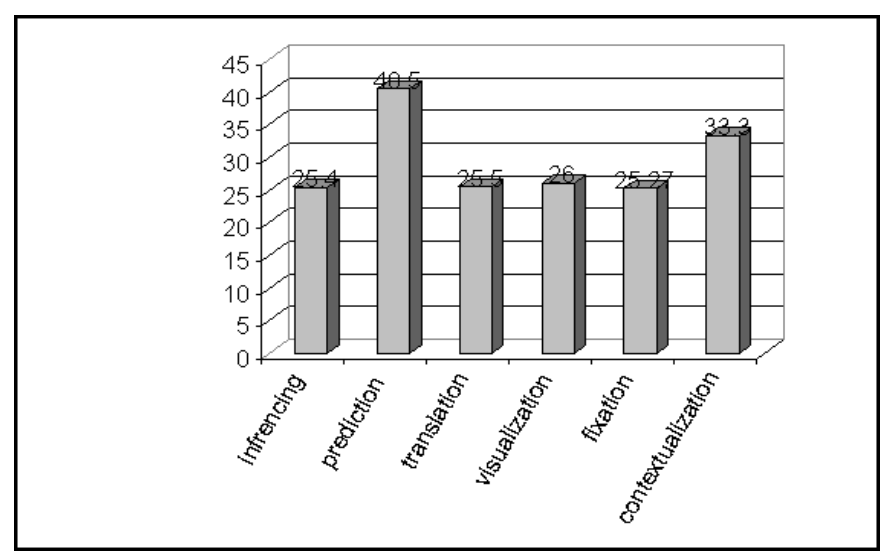

Figure 1. The mean frequency of cognitive strategies used by EFL learners in audio visual and audio groups

As figure 1 shows, "prediction (with the mean frequency of 40.5) and contextualization (with the mean frequency of 33.3) were the cognitive strategies which had the highest mean frequency and had been used by most of the participants.

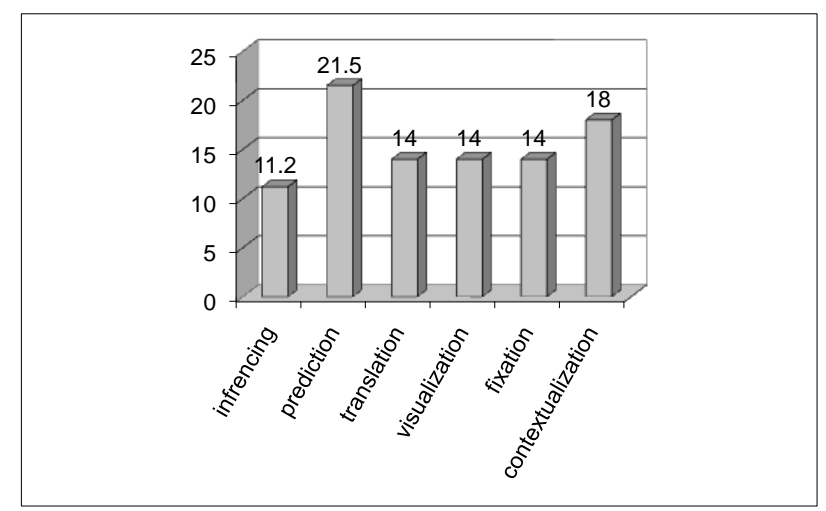

Figure 2. The mean frequency of strategies for audio-visual group 


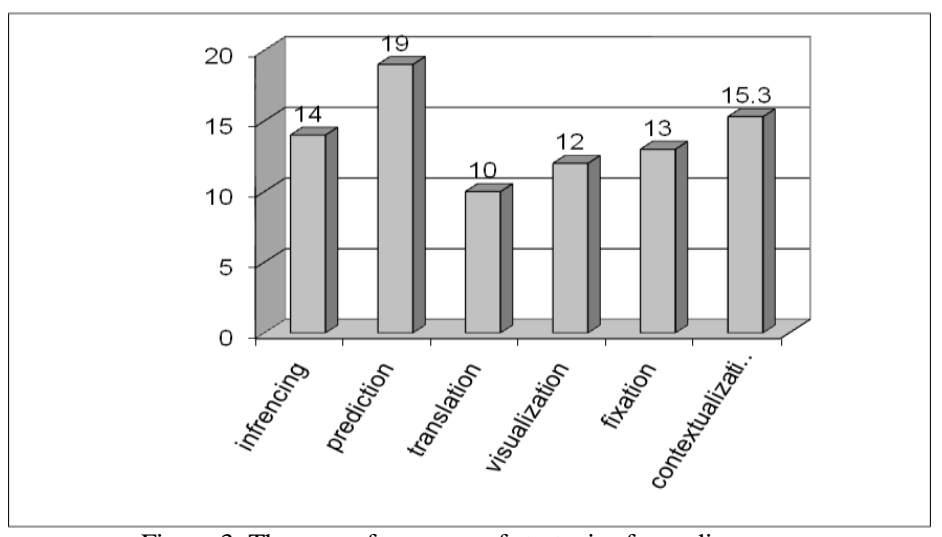

Figure 3. The mean frequency of strategies for audio group

According to the mean frequency of cognitive strategies which are shown individually in figures 2 and 3 , the audio visual group used prediction (21.50), translation (14), visualization (14), fixation (14) and contextualization (18) strategies more than the audio group. However, the audio group used inferencing (14) strategy more than the audio visual group.

In order to see the difference between the two groups in terms of tactics, a Chi- square test was run for each tactic. The results of two tactics which were statistically significant are shown in tables 3 and 4:

TABLE 3:

CHI- SQUARE TEST FOR THE FIRST TACTIC IN BOTH GROUPS.

Chi-Square Tests

\begin{tabular}{|c|c|c|c|c|c|}
\hline & Value & $\mathrm{df}$ & $\begin{array}{l}\text { Asymp. Sig. } \\
\text { (2-sided) }\end{array}$ & $\begin{array}{l}\text { Exact Sig. } \\
\text { (2-sided) }\end{array}$ & $\begin{array}{l}\text { Exact Sig. } \\
\text { (1-sided) }\end{array}$ \\
\hline Pearson Chi-Square & $7.878^{b}$ & 1 & .005 & \multirow{6}{*}{.009} & \multirow{6}{*}{.005} \\
\hline Continuity Correction & 6.712 & 1 & .010 & & \\
\hline Likelihood Ratio & 8.004 & 1 & .005 & & \\
\hline Fisher's Exact Test & & & & & \\
\hline $\begin{array}{l}\text { Linear-by-Linear } \\
\text { Association }\end{array}$ & 7.786 & 1 & .005 & & \\
\hline $\mathrm{N}$ of Valid Cases & 86 & & & & \\
\hline
\end{tabular}

a. Computed only for a $2 \times 2$ table

b. 0 cells $(.0 \%)$ have expected count less than 5 . The minimum expected count is 20 . 50 .

The first tactic was "other surrounding key words". According to table 3 the significant value is 0.005 which is smaller than 0.05 . Thus, it is statistically significant.

TABLE 4:

CHI-SQUARE TEST FOR THE FOURTH TACTIC IN BOTH GROUPS.

Chi-Square Tests

\begin{tabular}{|c|c|c|c|c|c|}
\hline & Value & $\mathrm{df}$ & $\begin{array}{l}\text { Asymp. Sig. } \\
\text { (2-sided) }\end{array}$ & $\begin{array}{l}\text { Exact Sig. } \\
\text { (2-sided) }\end{array}$ & $\begin{array}{l}\text { Exact Sig. } \\
\text { (1-sided) }\end{array}$ \\
\hline Pearson Chi-Square & $4.568^{b}$ & 1 & .033 & & \\
\hline Continuity Correction & 3.609 & 1 & .057 & & \\
\hline Likelihood Ratio & 4.647 & 1 & .031 & & \\
\hline Fisher's Exact Test & & & & .056 & .028 \\
\hline $\begin{array}{l}\text { Linear-by-Linear } \\
\text { Association }\end{array}$ & 4.515 & 1 & .034 & & \\
\hline $\mathrm{N}$ of Valid Cases & 86 & & & & \\
\hline
\end{tabular}

The fourth tactic was "information from pictures or the speakers' expressions". According to the findings in table 4 the significant value is 0.03 which is smaller that 0.05 . So, there is a statistically significant difference between these two groups regarding this tactic. 
TABLE 5:

PERCENTAGE OF PARTICIPANTS' RESPONSES FOR EIGHTEEN TACTICS IN BOTH GROUPS

\begin{tabular}{|c|c|c|c|}
\hline Tactics & Audio-visual & Only-audio & Total \\
\hline Tactic 1 & $37.2 \%$ & $67.4 \%$ & $52.3 \%$ \\
\hline Tactic 2 & $16.3 \%$ & $25.6 \%$ & $20.9 \%$ \\
\hline Tactic 3 & $16.3 \%$ & $18.6 \%$ & $17.4 \%$ \\
\hline Tactic 4 & $39.5 \%$ & $18.6 \%$ & $29.1 \%$ \\
\hline Tactic 5 & $20.9 \%$ & $32.6 \%$ & $26.7 \%$ \\
\hline Tactic 6 & $23.3 \%$ & $11.6 \%$ & $17.4 \%$ \\
\hline Tactic 7 & $76.7 \%$ & $76.7 \%$ & $76.6 \%$ \\
\hline Tactic 8 & $44.2 \%$ & $41.9 \%$ & $43.0 \%$ \\
\hline Tactic 9 & $20.9 \%$ & $11.6 \%$ & $16.3 \%$ \\
\hline Tactic 10 & $60.5 \%$ & $46.5 \%$ & $53.5 \%$ \\
\hline Tactic 11 & $4.7 \%$ & $9.3 \%$ & $7.0 \%$ \\
\hline Tactic 12 & $0 \%$ & $2.3 \%$ & $1.2 \%$ \\
\hline Tactic 13 & $46.5 \%$ & $34.9 \%$ & $40.7 \%$ \\
\hline Tactic14 & $7.0 \%$ & $2.3 \%$ & $4.7 \%$ \\
\hline Tactic 15 & $65.1 \%$ & $81.4 \%$ & $73.3 \%$ \\
\hline Tactic 16 & $51.2 \%$ & $51.2 \%$ & $51.2 \%$ \\
\hline Tactic 17 & $34.9 \%$ & $23.3 \%$ & $29.1 \%$ \\
\hline Tactic 18 & $39.5 \%$ & $32.6 \%$ & $36.0 \%$ \\
\hline
\end{tabular}

\section{DISCUSSION AND CONCLUSION}

The purpose of this study was to investigate the impact of listening mode on the choice of cognitive strategies in listening comprehension. The first question addressed the difference between the audio-visual and the only-audio material. In response to this question, a t-test was used to analyze the data. The results showed no statistically significant difference between the audio- visual and the only -audio groups.

The finding of this research is in line with Tina Lynn Ware (1999) and Coniam's (2001) findings. Tina Lynn Ware and Coniam did not come across any statistical significant difference between the scores in the audio visual and the only -audio groups.

The researches that have been done in listening comprehension and strategy use are mostly in the area of metacognitive strategies and there is not enough research in the area of cognitive strategies. This study tried to discover the cognitive strategies that learners use in different mode of listening comprehension.

As it is shown in figure1, prediction and contextualization were the most frequent strategies which were used by most of the participants. In terms of tactics, 76\% of the participants used tactic 7: "I use what I have heard to guess what the next part is".

"Memorizing the pronunciation to check the meaning later" ( tactic number 15: 73.3\%), imagining a picture of what they hear ( tactic number 10: 53.5\%), other surrounding key words ( tactic number 1: $52.3 \%$ ) and placing input in a social or linguistic context (tactic number 16: 51.2\%) were the tactics which had respectively the highest level of use.

Goh (2002) did a research titled "Learners' self report on comprehension and learning strategies for listening". The result of Goh's Study showed that inferencing and contextualization strategies had the highest level of use. More than $75 \%$ of his respondents used Visual clues, contextual clues and familiar context words to help them bridge gaps in their understanding. In Goh's study, inferencing and contextualization were the most frequent cognitive strategies while in this research study, prediction and contextualization were the two most frequent strategies used by participants of the two groups. The result of this study was some how in agreement with Goh's study. Contextualization was one of the most frequent strategies used by the majority of Chinese and Iranian Learners. As Skehan (1998) pointed out, learners who lack knowledge of the target language will most likely use their "schematic and contextual knowledge to overcome their systematic limitations." (p. 15).

In terms of differences between the two groups in tactics, as figures 2 and 3 show, the audio group used inferencing strategy more than audio- visual group while visualization, fixation, translation and contextualization were the strategies more frequently used in the audio-visual group. Moreover, there is statistical significant difference between the two groups in using these two tactics: "using other surrounding words" and "information from the pictures or the speakers' expression."

\section{IMPLICATIONS OF THE STUDY}

The study aimed to discover the influence of listening mode on the choice of cognitive strategies in listening comprehension. The findings indicate that there is no significant difference between the audio-visual and the only audio materials. The findings imply that teachers should provide their students with both the audio- visual and the only audio materials in their laboratory courses to help their students increase their listening comprehension in foreign or second language in different modes. Each mode has its own characteristics. For example, in audio-visual materials there is a combination of pictures, sound and text and students can fill the incomprehensible parts through available pictures 
moreover, it assists teachers to bring the outside world to the class. Providing learners with the only audio materials increases learners' concentration as there is no picture to distract learners' attention.

The results obtained from the Techniques for Learning to Listen Questionnaire (TELL) responses in cognitive strategies and tactics can be valuable and practical in teaching. Students can use the TELL for self-evaluation purposes to discover their current level of cognitive awareness. Moreover, the TELL can be specifically useful to positively affect students' attitudes and their perceptions of the listening process so that they can become skilled listeners who manage their own cognitive comprehension processes automatically.

The TELL can also be used as consciousness-raising tool for teachers. Teachers can discover the most frequent used cognitive strategies by administrating TELL to all the students. When teachers discover, for example, that the class as a whole is under using a particular strategy or set of strategies (such as prediction or inferencing), instruction can be adjusted to place greater emphasis on predicting or using available information to guess meaning of new items before beginning a listening task and teachers find this chance to teach cognitive strategies explicitly. Therefore, explicit teaching of strategies in different modes can help students to overcome their difficulties in listening comprehension and it can raises students' awareness of the process of listening.

\section{APPENDIX A TECHNIQUES FOR LEARNING TO LISTEN QUESTIONNAIRE (TELL) (GOH 2002)}

Inferencing (When I do not understand something, I guess the meaning by using the following)

1. other surrounding key words

2. experience and knowledge about the topic

3. knowledge about the English language

4. information fro pictures or the speaker's expression

5. knowledge about the situation

Prediction (I do this to help my comprehension)

6. Before I hear anything, I try to guess what will be said

7. I use what I have just heard to guess what the next part is

Translation (Before trying to understand everything)

8. I first translate some difficult words in to my mother tongue

9. I first translate the whole sentence in to my mother tongue

Visualization (When I am listening)

10: I imagine a picture of what I hear

11. I picture in my mind the spelling of some words

Fixation (When I hear words I do not recognize)

12. I stop to think about the spelling of unfamiliar words

13. I try to repeat the sound of unfamiliar words

14. I stop to think hard what unfamiliar words mean

15. I try to memorize the pronunciation so as to check the meaning later

Contextualization ( I do this to help my comprehension)

16. when I hear something new, I think about the other information related to it

17. I relate what I hear to other things the speaker has just said

18. I use my experience and knowledge to expand the meaning of what I get

\section{REFERENCES}

[1] Allan, M., (1985). Teaching English With Video. Longman, London.

[2] Altman, R. (1990). Toward a new video pedagogy: the role of schema theory and discourse analysis. IALL Journal of Language Learning Technologies 27, 11-26.

[3] Bechtel, W. \& A. Abrahamsen. (1991). Connectionism and the mind: An introduction to parallel processing in networks. Oxford: Blackwell

[4] Chamot, A. U. (2005). Language learning strategy instruction: Current issues and research. Annual Review of Applied Linguistics, 25, 112-130.

[5] Coniam, D. (2001). The use of audio or video comprehension as an assessment instrument in the certification of English language teachers: A case study. System 29, 1-14.

[6] Dörnyei, Z. (2005). The psychology of the language learner: Individual Differences in second Language Acquisition. Mahwah, NJ: Lawrence Erlbaum Associates.

[7] Feak, C. B. \& J. Salehzadeh (2001). Challenges and issues in developing an EAP video listening placement assessment: A view from one program. English for Specific Purposes 20, 477-493.

[8] Flowerdew, J., \& Miller, L. (2005). Second language listening: Theory and practice. New York: Cambridge University Press

[9] Geddes, M., White, R., (1978). The use of semi-scripted simulated authentic speech in the listening comprehension. Audiovisual Language Journal 16, 137-145.

[10] Ginther, A. (2002). Context and content visuals and performance on listening comprehension stimuli. Language Testing 19, $133-167$. 
[11] Goh, C. (2002). Learners' self-reports on comprehension and learning strategies for listening. Asian Journal of English Language Teaching 12, 46-68.

[12] Hulstijn, J. H. (2003). Connectionist models of language processing and the training of listening skills with the aid of multimedia software. Computer Assisted Language Learning 16, 413-425.

[13] Lonergan, J. (1984). Video in Language Teaching. Cambridge University Press, Cambridge.

[14] Lynch, T. \& D. Mendelsohn. (2002). Listening. In N. Schmitt (ed.), An introduction to applied linguistics. London: Arnold, $193-210$.

[15] Macaro, E. (2001). Learning strategies in foreign and second language classrooms. New York: Ernesto Macaro.

[16] Macaro, E. (2006). Strategies for language learning and for language use: Revising the theoretical framework. The Modern Language Journal, 90(iii), 320-337.

[17] McCafferty, S.G. (2002). Gesture and creating zones of proximal development for second language learning. Modern Language Journal, 86, 192-203.

[18] McGovern, J. (Ed.), (1983). Video Applications in English Language Teaching, ELT Documents 114, 1st Edition. British Council, London.

[19] Nunan, D. (1998). Approaches to Teaching listening in the Language Classroom. Paper Presented at the Korea TESOL Conference, Seoul.

[20] Oxford, R. L. (1990). Language learning strategies: What every teacher should know. Boston, MA: Heinle \& Heinle.

[21] Oxford, R. L. (1996). Preface: Why is culture important for language learning strategies? In Oxford (Ed.) Language learning strategies around the world: Cross-cultural perspectives (Technical Report \#13) (pp. ix-xv). Honolulu, HI: University of Hawai'i, Second Language Teaching \& Curriculum Center.

[22] Oxford, R. L. (1999). Learning strategies. In B. Spolsky (Ed), Concise encyclopedia of educational linguistics (pp. 518-522). Oxford: Elsevier.

[23] Phillips, L.K., (1995). Testing. In: Galloway, V., Herron, C. (Eds.), Research Within Reach II. Southern Conference on Language Teaching. Valdosta, GA, pp. 161 \pm 174 .

[24] Rost, M. (2002). Teaching and researching listening. London, UK: Longman.

[25] Schmeck, R. R. (1988) .Individual differences and learning strategies. In: Weinstein, C.E., Goetz, , E. T., Alexander, P. A. (Eds.),Learning and Study Strategies : Issues in Assessment, Instruction, and Evaluation .Academic Press, San Diego.

[26] Secules, T., Herron, C., Tomassello, M. (1992). The effect of video context on foreign language learning. Modern Language Journal 76, 480-490.

[27] Segalowitz, N. (2003). Automaticity and second language. In C. Doughty \& M. Long (eds.), The handbook of second language acquisition. Oxford: Blackwell Publishing, 382- 408.

[28] Snowman, J. (1986). Learning tactics and strategies. In: Phye, G. D., Andre, T. (Eds.), Cognitive instructional Psychology: Components of Classroom Learning. Academic Press, New York.

[29] Stempleski, S., Arcario, P. (1992). Video in Second Language Teaching: Using, Selecting, and Producing Video for the Classroom. Teachers of English to Speakers of Other Languages, Alexandria, VA.

[30] Tina Lynn Ware. (1999). A Comparison of Audio-Only Versus Audio-Visual Language Instruction in First-Year UniversityLeevel Spanish.

[31] Vandergrift, L. (2003). From prediction through reflection: Guiding students through the process of L2 listening. The Canadian Modern Language Review, 59(3), 425-440.

[32] Van Duzer, C. (1997). Improving ESL Learners' Listening Skills: At the Workplace and Beyond. Washington D.C.: National Clearinghouse foe ESL Literacy Education.

[33] Wagner, E. (2007). Are they watching? Test-taker viewing behavior during an L2 video listening test. Language Learning \& Technology 11.1, 67-86.

Rezvan Zonoubi was born in NAjafabad, Isfahan, Iran. She received her B.A degree in Teaching English as a foreign language from Islamic Azad university of Najafabad, Najafabad, Isfahan, Iran in 2003, her M.A degree in TEFL from Islamic Azad Khorasgan University, Isfahan, Iran.

She is teaching English to university students in Islamic Azad najafabad University. She also has been teaching English for 7 years in different institutes. 